\title{
Introspeksi Masa Lalu Terfragmentasi dan Narasi Bermoda Percakapan dalam Yang Sudah Hilang oleh Pramoedya Ananta Toer
}

\author{
Thafhan Muwaffaq ${ }^{1}$ \\ ${ }^{1}$ Program Studi Sastra Inggris, Fakultas Sastra, Universitas Al Azhar Indonesia, Jalan \\ Sisingamangaraja, Kompleks Masjid Agung Al Azhar, Kebayoran Baru, Jakarta Selatan 12110 \\ Penulis untuk Korespondensi/E-mail: thafhan.muwaffaq@uai.ac.id
}

\begin{abstract}
Abstrak - Meskipun Pramoedya Ananta Toer telah dianggap penulis fiksi prominen di lingkup kesusastraan, ternyata salah satu karyanya yang berprestasi (Cerita dari Blora) belum mendapat sorotan telaah sastra. Makalah ini mengambil satu judul cerpen dari antologi itu secara spesifik yaitu Yang sudah Hilang. Pertanyaaan yang dilontarkan di sini adalah bagaimana pembahasaan teks cerpen tersebut membangun representasi adegan referen atau model situasi. Prosesi teks semiotika kognitif digunakan di sini, khususnya prinsip moda kesadaran Chafe, untuk menghasilkan interpretasi yang memperhitungkan objektivitas dalam proses inferensial berbasis pengalaman pemaknaan. Sehubungan dengan hal itu saya berargumen pembahasaan dalam teks menghasilkan model situasi simulasi pengenangan masa lalu terfragmentasi secara introspektif dalam moda percakapan. Masa lalu yang dikenang terfragmentasi dan menghasilkan ironi dramatik. Model situasi tersebut kelihatannya lebih menampilkan elegansi Pram sebagai penulis yang bermain bahasa dan makna, ketimbang fenomena kontekstual yang terlalu lekat dengan subjektivitas.
\end{abstract}

Kata Kunci - Prosesi Teks Semiotika Kognitif, Model Situasi, Moda Kesadaran, Ironi Dramatic

Abstract - Despite the popularity of Pramoedya Ananta Toer as a promninent and controversial Indonesian literary figure, his prestigious short story anthology entitled Cerita dari Blora seems rather poorly understudied. By far, the existing literary criticism on this work provides highly contextual and subjective interpretation. This paper then is aimed to reading closely Yang Sudah Hilang, one of short story from the anthology. Question raised here is how does language of the text build representation of referent scene or situation model. This study uses cognitive semiotics text processing, an approach that takes account objective evidence and experientiallybased inference. Conscious mode principle, proposed by Chafe (1994), is employed as theoretical perspective in drawing interpretation. It is argued that language in the text built a situation model wherein protagonist is simultaneously memorizing her loss and telling to readers her fragmented past in conversational mode. Moreover, despite her introspection the protagonist does not seem aware what brings her to the present moment where she is already losing important people of her life. In general, the situation model argued may be offered as a standard interpretation of Yang sudah Hilang which is far from subjectivity and derived from meaning experience triggered by language.

Keywords - Cognitive Semiotics Text Processing, Situation Model, Conscious Mode, Dramatic Irony 


\section{PENDAHULUAN}

$\mathrm{S}$ elama ini Pramoedya Ananta Toer (19252006), yang akrab dipanggil 'Pram', telah dianggap sebagai tokoh sastrawan menonjol karena karya-karyanya yang memberikan perspektif atas sejarah, budaya, dan hubungan sastra dengan politik kuasa di Indonesia. Citra Pram dan karyanya juga dihubung-hubungkan dengan '-isme' tertentu. Yang barusan boleh jadi suatu bahan perbincangan yang lazim mengenai Pram dan karyanya. Namun sangat jarang yang mengupas bagaimana Pram mengolah elemen linguistik (ataupun nonlinguistik) dalam membangun naratif yang didasari niat pembuatan-pemaknaan.

Terdapat tulisan-tulisan tentang keterhubungan Pram dengan politik Indonesia (GoGwilt, 2003). Suara pertentangan Pram telah ditelaah secara komparatif yang mengambil konteks otoriter dan liberal (GoGwilt, 2003). Dari sini bolehlah seseorang berpendapat bahwa karya Pram memberikan perspektif yang fleksibel terhadap konteks yang berbeda.

Di antara banyaknya karya Pram, Cerita dari Blora adalah salah satu antologi cerpen yang terbit pertama kali di tahun 1952. Setahun kemudian Badan Musyawarah Kebudayaan Nasional menamakan Cerita dari Blora sebagai kumpulan cerpen terbaik. Ini merupakan prestasi yang mengesankan. Antologi Cerita dari Blora telah diterjemahkan ke dalam sembilan bahasa asing.

Meski demikian, kelihatannya Cerita dari Blora kurang mendapat perhatian dari kritikus dan pengkaji sastra dibanding tetralogi Buru. Tipikal kajian terhadap karya Pram mengambil tetralogi Buru (yaitu: Bumi Manusia, 1980; Anak Semua Bangsa, 1981; Jejak Langkah, 1985; Rumah Kaca, 1988). Suatu hal lazim pula kajian sastra atau budaya terhadap Pram dan karya-karyanya dibenturkan dengan wacana poskolonialisme dan sejarah (Bahari, 2007; Niekerk, 2003; Roosa dan Ratih, 2001).

Kajian-kajian yang sudah ada, yang telah menelaah tetralogi Buru, menyumbangkan perspektif dan penerangan terhadap karya pram. Salah satu pandangan menarik atas tetralogi Buru adalah Foulcher (1981), yang mengevaluasi Bumi Manusia dan Anak Segala Bangsa. Ia menyatakan bahwa Pram memiliki audiens yang dapat dijangkaunya melalui penggunaan bahasanya. Selanjutnya ia mengatakan bahwa karya-karya Pram tersebut mengandung kekuatan sejarah, yang lantas membuat pembaca terpapar dengan kekuatan itu. Selain tetralogi Buru, telaah karya sastra yang ada umumnya mengkaji novel Pram seperti Mereka Yang Dilumpuhkan (Faruk, 2008) dan Gadis Pantai (Supriyadi, 2005; Muzakka, 2017).

Makalah ini mengambil bahasa dan makna pada karya karangan Pram sebagai isu sentral. Namun menyadari keberadaan sorotan kajian sastra yang cenderung jatuh pada tetralogi Buru atau novel-novelnya yang lain, makalah ini akan mengalamatkan isu tadi kepada Cerita dari Blora. Antologi tersebut diakui sebagai antologi cerpen terbaik nasional, versi Badan Musyawarah Kebudayaan Nasional setahun setelah ia terbit, antologi ini minim perhatian penelaahan kritis. Adapun kajian yang menyinggung Cerita dari Blora baru sebatas memberikan interpretasi dari kaca mata feminis (Hayati, 2012). Dan, interpretasi tersebut nampaknya tidak begitu memberikan perhatian khusus atas bahasa naratif tekstual Pram.

Perlu diperjelas, interpretasi feminisme atas Cerita dari Blora yang dilakukan Hayati (2012) menjelaskan adanya representasi marginalisasi, subordinasi, stereotip, dan kekerasan atas perempuan. Interpretasi itu maju melalui proses epistemik yang cermat. Dalam kata lain, bisa saja Cerita dari Blora merepresentasikan ketidakadilan gender. Tapi tak bisa dipungkiri ada yang bercelah pada interpretasi itu.

Interpretasi Hayati, sebagaimana yang disebutkan tadi, belum menyentuh tataran ide dan konsep makna dari ruang meta-narasi yang didatangkan oleh pengunaaan bahasa. Penggunaan bahasa juga tidak bisa lepas dari bagaimana pikiran kita mengoperasikan proses pemaknaan di dalam kepala. Sehubungan hal itu aspek kognitif seharusnya diperhitungkan dalam menginterpretasi. Namun demikian, Interpretasi tawaran Hayati merujuk kepada deksripsi yang mengkontekstualisasikan gejalagejala fenomena yang kemudian dipandang melalui perspektif feminisme. Ini dilakukan tanpa mengambil catatan tentang hubungan bahasa dan naratif, sebagaimana menimbang pemaknaan yang dihasilkan oleh teks. 
Setidaknya celah itu tertutup dalam makalah ini, yang menelaah salah satu cerpen Cerita dari Blora, yaitu Yang Sudah Hilang. Tawaran interpretasi makalah ini akan melihat aspek permukaan teks sampai ke tataran meta-narasi. Ini dilakukan dengan memperhitungkan hubungan bahasa dan aspek kognitif yang bertanggung jawab atas pemaknaan. Dengan demikian, makalah ini mempertanyakan bagaimana pembahasaan Pram dalam Yang Sudah Hilang membangun suatu pemaknaan yang kemudian dialami pembaca.

Tujuan makalah ini adalah menelaah hubungan bahasa-makna, dengan memandang kognisi, yang membangun suatu representasi adegan referen atas cerpen Pram di kepala pembaca. Makalah ini memandang pembahasaan lekatlekat dalam menawarkan interpretasi yang menggunakan prosesi tekstual semiotika kognitif. Baik elemen linguistik ataupun nonlinguistik dapat dianggap sebagai substansi yang dianalisis dan dasar interpretasi. Namun, analisis yang dilakukan di sini hanya pada elemen linguistik.

Pendekatan semiotika kognitif terhadap prosesi teks digunakan di sini untuk menelaah cerpen Yang Sudah Hilang. Atas dasar itu penelaahan teks di makalah ini berpandangan yang lepas dari '-isme' apapun. Dalam kata lain, makalah ini mengesampingkan kesan-kesan yang sangat kontekstual yang seolah dihadirkan teks. Dengan demikian bisa diafirmasi bahwa bias subjektivitas penelaah tidak campur tangan dalam proses interpretasi di sini.

Pendekatan semiotika kognitif menganggap teks sebagai teks terserah sastra atau bukan. Namun pengambilan teks sastra sebagai objek telaah dalam pendekatan ini disebabkan oleh dugaan adanya pembentukan intensi pemaknaan penulis. Teks berita pastilah cenderung berusaha seinformatif mungkin. Tapi, ada motivasi yang belum tentu bisa diketahui dari penggunaan majas atau upaya pembahasaan tak lazim yang dilakukan penulis sastra dalam genre fiksi (Friend, 2012). Tak perlu disebutkan, pendekatan ini sama sekali tak bermaksud mengejar niat penulis. Pendekatan ini melihat pembentukan intensi makna yang dilakukan melalui penggunaan fitur-fitur linguistik maupun non-linguistik secara tekstual, yang pada dasarnya bisa dilacak.
Dengan asumsi dasarnya yang menganggap penulis memainkan bahasa dengan intensi pemaknaan, seseorang yang menggunakan pendekatan semiotika kognitif terhadap teks akan mengacu kepada spesifikasi fitur-fitur linguistik. Dengan fitur-fitur tersebut representasi suatu teks lengkap, koheren, dan menyertai keterhubungan penulis atau narator dengan representasinya dapat diterangkan. Dalam hal ini setidaknya ada tiga isu yang diperhatikan oleh semiotika kognitif: (1) efek makna (disebut juga dengan efek semantik atau efek semiotika), (2) tiga tingkatan teks yaitu struktur permukaan, dasar teks, dan model situasi (van Dijk \& Kintsch, 1983; Kintsch et al., 1990), dan (3) prinsip pemasangan bentukmakna. Perlu dicatat bahwa pengurutan tiga isu tersebut bukanlah hal yang perlu diperhatikan.

Di makalah ini saya akan menjelaskan model situasi yang dibangun oleh pembahasaan Pram dalam cerpen Yang Sudah Hilang. Model situasi diperoleh melalui proses inferensial, atau proses penangkapan wawasan dari pembacaan teks (van Dijk \& Kintch, 1983). Dalam eksperimen yang dilakukannya secara cermat, mereka menemukan pembaca dapat menggali wawasan dari makna pernyataanpernyataan yang tertera dalam tubuh teks secara eksplisit. Wawasan hasil proses inferensial itu bisa dianggap sebagai makna implisit yang keberadaannya ada di bawah struktur permukaan teks. Dari sana mereka memproposisikan tiga tingkatan pemaknaan teks yaitu, struktur permukaan (yaitu: apa yang muncul pada teks), makna dasar teks (yaitu: wawasan eksplisit dari pernyataan eksplisit struktur permukaan), dan model situasi (yaitu: hasil inferensi atas teks). Secara sederhana model situasi merupakan adegan referen yang direpresentasikan teks.

Model situasi, atau adegan referen yang direpresentasikan teks, adalah suatu hal yang sifatnya meta-narasi atau melampaui apa yang ditampilkan teks itu sendiri. Di sini saya akan menawarkan model situasi dengan cara menginferensi apa yang tertera pada teks Yang Sudah Hilang. Model situasi ini akan saya tawarkan sebagai rumusan interpretasi yang berdiri di atas perhitungan penggunaan bahasa sebagaimana tertera dalam teks. Dalam menyampaikan saya ke hasil inferensi, saya akan menggunakan kerangka kerja teoretik yang ada dalam ranah prosesi teks semiotika 
kognitif yang berfokus kepada pembuatan makna.

Dalam semiotika kognitif ada beberapa alat pembentuk makna yang bisa disinggung dalam prosesi informasi untuk penelaahan teks. Di antaranya struktur naratif atau koherensi (Dirven dan Verspoor, 2004), perspektif dalam naratif (Gennette, 1980; Stenzel, 1981; Herman, 2009; Talmy, 2000), skemata (Emmot dan Alexander, 2014) dan properti kesadaran sebagai suatu moda narasi (Chafe, 1994). Penelaahan dalam makalah ini akan menggunakan kerangka teori moda kesadaran Chafe pada teks fiksi (sudut pandang) orang pertama.

\section{Moda Perpindahan Imediasi dalam Tulisan Fiksi Orang Pertama: Kerangka Kerja Teoretik}

Dalam buku Discourse Consciousness and Time (1994), Chafe menjelaskan ketertarikannya atas aliran dan perpindahan pengalaman alam sadar yang berpengaruh terhadap bentuk bahasa, penjelasan mengenai fenomena bahasa, dan pemahaman aspek dasar di ranah kehidupan mental. Menurutnya ada keuntungan dari mempelajari kesadaran dengan merujuk kepada bahasa, khususnya dalam hal pembuktian. Bukti yang didatangkan dari pembahasaan akan memperjelas keterkaitan introspeksi yang terjadi dalam benak seseorang dengan apa yang diucapkannya ketika bicara.

Model moda kesadaran Chafe dihasilkan penelitian-penelitian analisis percakapan. Sebagai perkembangan model kesadaran langsung dan perpindahan di situasi percakapan (lihat Chafe, 1994), Chafe memproposisikan model kesadaran perpindahan imediasi sebagai moda yang beroperasi dalam tulisan fiksi orang pertama. Gambar 1 mengilustrasikan moda perpindahan imediasi dalam tulisan fiksi orang pertama Chafe.

Chafe menyatakan terdapat tuntutan status spesial terhadap logika dalam tulisan fiksional. Ia mengimplikasikan bahwa penulis belum tentu, kalau tidak, bukanlah diri yang bercerita sebagaimana memproduksi bahasa yang berwujud teks. Dengan demikian, diri yang ada dalam teks adalah invensi penulis sebagaimana penceritaannya merupakan hasil kreasi pula. Diri fiksional ini bisa diakui ataupun tak diakui, dan hal ini dideterminasikan oleh bahasa yang ada pada teks. Catatan penting lainnya mengenai kesadaran dan bahasa teks fiksional adalah kesadaran diri fiksional mewakili ide yang direpresentasikan bahasa teks itu sendiri.

Kekhususan logika menimbulkan perbedaan karakteristik antara penceritaan dalam konteks percakapan dengan penceritaan teks fiksional. Yang pertama umumnya menyituasikan pengingatan dilakukan oleh seorang pencerita, dan kesadaran mewakili berkoinsiden dengan kesadaran diwakili. Sementara yang kedua, dalam teks fiksional, meskipun berasal pada diri yang sama kesadaran diwakili dapat tampil dengan sifat yang berbeda dari kesadaran mewakili yang bercerita.

Chafe menggunakan The Ox Bow Incident oleh Walter van Tilburg Clark (1940) untuk mendemonstrasikan bahasa fiksi yang berbeda. Hal pertama yang diterangkannya adalah adanya perbedaan secara bahasa pada teks fiksional meski penceritaannya bisa dianggap berangkat melalui gaya naratif di situasi percakapan. Perbedaannya adalah penggunaan ruang percakapan dalam teks fiksi yang tidak alami dibanding percakapan pada umumnya. Penguasaan ruang percakapan dalam teks fiksional dapat memanjang sampai ke halaman yang banyak kuantitasnya, yang mana hal itu sendiri sangat sulit dijumpai dalam percakapan. Selain itu audiens pencerita tak terspesifikasi dalam teks fiksional, sehingga siapapun bahkan bisa jadi audiens pencerita seketika ia membaca teks tersebut.

Perpindahan imediasi kesadaran, menurut Chafe, adalah penggabungan antara kesadaran mewakili introvert, yang proksimal atau dekat dengan audiens, dan kesadaran diwakili ekstrovert distal, yang mengalami kejadian dan keadaan langsung. Dalam perpindahan imediasi terjadi pemisahan antara narator fiksional dengan kesadaran diwakili, meskipun keduanya milik diri fiksional yang sama. Pemisahan ini dibolehkan oleh bahasa tulisan yang menimbulkan desituasi, sehingga melemahkan kopresensi antara pemroduksi bahasa dengan ide yang dituliskannya. 


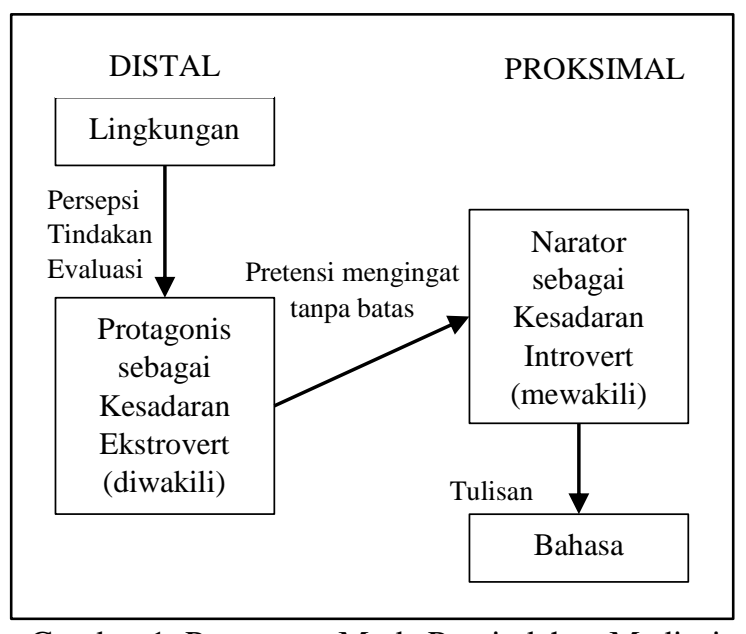

Gambar 1. Penerapan Moda Perpindahan Mediasi Chafe atas Teks Yang Sudah Hilang

Keunikan perpindahan imediasi dalam bahasa tulisan adalah kebisaannya merentang ke seluruh cerita, sehingga menjadikannya lebih global. Selain itu moda ini lebih kompleks dalam sifatnya yang tak memiliki batasan dalam penggunaan kala bahasa. Selanjutnya, kesadaran distal dalam moda ini tak terbelenggu. Inilah yang mencirikan keunikan fiksi dengan penceritaan pada ranah percakapan. Sering dijumpai dalam situasi percakapan seseorang mengingat ketika menceritakan sesuatu. Tetapi dalam fiksi, pengingatan untuk bercerita merupakan suatu hal yang khusus sehingga kesadaran distal dapat mengakses lingkungan langsung sebagaimana mengalami ulang kejadian dan keadaan yang telah lewat. Kekhususan itu disebut Chafe sebagai 'pretensi mengingat tanpa batas'.

Pembuktian imediasi, atau kesadaran dalam moda langsung, dilakukan oleh Chafe dengan mengacu pada kualitas ekstroversi yang muncul dalam teks. Salah satu kualitas ekstroversi adalah kontinuitas yang merupakan aliran rangkaian kejadian dan bingkai referen milik narator. Keduanya dapat direfleksikan kepada keadaan alami di mana seseorang yang berinteraksi dengan lingkungan langsungnya mendapati kesadarannya mengalir mengikuti apa yang aksesibel di sekitarnya. Sementara itu, bingkai referen atau bingkai semantik, yang disinyalir oleh artikel definit (dalam bahasa Inggris) menyatakan pengetahuan pembicara atas objek yang dimaksud. Terjadinya dua hal tersebut membuat situasi percakapan tidak lazim. Tetapi dalam teks fiksional, terdapat pengecualan atas dua hal tadi sebagaimana keduanya merupakan ciri yang tipikal.

Kualitas ekstroversi lainnya adalah detil yang bersyarat titik perhatian kesadaran langsung. Dalam teks fiksional, sangat tipikal narator merincikan sesuatu dalam gilingan yang halus. Hal semacam ini sulit dilakukan pada pengingatan yang umum. Untuk sifat ini Chafe berspekulasi bahwa detil dalam gilingan halus dihasilkan pengingatan dan pengkhayalan.

Imediasi deiksis adalah ciri kualitatif ekstroversi. Hal ini dinyatakan oleh adverbial deiktik (misalnya: 'now' atau 'today' dalam bahasa Inggris). Kedua adverbia tersebut berhubungan dengan pusat deiktik kesadaran diwakili terkait kejadian dan keadaan di lingkungan langsung. Chafe berpendapat adverbia tersebut berkoinsidensi dengan kala lampau yang melokasikan kejadian atau keadaan yang telah mendahului kesadaran mewakili. Lebih lanjut, di dalam percakapan penggunaan koinsidensi adverbia dan kala lampau menimbulkan ketidakcocokan. Akan tetapi, terpisahnya kesadaran mewakili dengan kesadaran diwakili menghilangkan ketidakcocokan tersebut.

Kala lampau dijadikan Chafe bukti terjadinya perpindahan kesadaran dari situasi temporal sekarang ke masa yang telah dilampaui (ataupun yang akan datang). Ini karena kala lampau mereferensikan temporalitas antara kesadaran diwakili yang mendahului kesadaran mewakili, sebagaimana menyediakan pusat deiktik bagi kala tersebut. Naratif dalam percakapan memberitakan kejadian dalam ingatan atau khayalan, dan kala lampau mengesankan kealamian properti percakapan itu.

Lebih lanjut, Chafe sudut pandang orang pertama menyatakan ekuivalensi diri kesadaran ekstrovert dengan kesadaran introvert. Artinya, identitas kedua kesadaran tersebut sama dengan diri yang memproduksi bahasa. Dengan demikian diri tersebut adalah titik yang jadi sudut pandang. Penggunaan pronomina orang pertama adalah bukti bagi keberadaan sudut pandang orang pertama. Selanjutnya, di dalam teks terdapat persepsi, evaluasi, tindakan, dan introspeksi diri yang jadi sudut pandang tersebut. 
Meskipun seorang pembaca mengetahui keberadaan narator sebagai instansi pencerita, namun menurut Chafe kesadaran narator seketika ia memproduksi bahasa ceritanya tidaklah relevan. Irelevansi itu meniadakan pengakuan terhadap narator selaku kesadaran mewakili. Kendati demikian, kesadaran mewakili bisa saja diakui melalui bahasa penceritaannya, sehingga menjentikkan kongruensi singkat antara kesadaran diwakili dan kesadaran mewakili, menerangkan pula keberadaan kesadaran mewakili secara terangterangan.

Dalam menjelaskan bagaimana model moda perpindahan imediasi beroperasi Chafe menggunakan bahasa Inggris. Terdapat perbedaan sistematik antara bahasa tersebut dengan bahasa teks yang akan ditelaah di sini. Ini merupakan tantangan tersendiri ketika seseorang menggunakan model tersebut sebagai perspektif teoretiknya ketika melakukan telaah tekstual. Namun demikian, kelihatannya ada kemungkinan ditemukannya keunikan-keunikan apabila seseorang menggunakan model tersebut dalam menelaah teks berbahasa Indonesia sebagaimana yang terjadi di sini.

\section{ANALISIS}

\section{Moda Perpindahan Imediasi}

Hal pertama yang perlu diutarakan adalah diri berkesadaran dalam teks Yang Sudah Hilang bukanlah milik Pram. Kesadaran yang ada di sana milik diri yang sengaja dibuat oleh Pram. Mode perpindahan imediasi dalam teks Yang Sudah Hilang dapat diterapkan dalam skema yang telah diajukan Chafe (1994) sebagaimana dipampangkan oleh Gambar 1.

Diri yang ada dalam teks adalah fiksional. Siapapun boleh saja menganggap itu Pram, namun label fiksi semi-otobiografi pada antologi Cerita dari Blora sendiri sudah cukup menepis anggapan itu. Diri fiksional dalam teks Yang Sudah Hilang berperan ganda, sebagai instansi penarasi (atau narator) dan protagonis.

Di sini ada perbedaan spasiotemporal antara kedua peran tersebut. Tetapi, kemampuan diri fiksional sebagai narator dalam melakukan pretensi mengingat tanpa batas membuat perbedaan tadi tidak mengungkung kedua peran pada ruang dan waktunya masing-masing. Dalam hal ini, kemampuan pretensi itu memampukan narator bukan lagi sekadar mengingat melainkan, mengalami ulang pengalaman masa lalunya.

\section{Moda Imediasi}

Keberadaan moda imediasi yang dimanifestasikan oleh kontinuitas, detil, dan deiksis imediasi. Tiga hal tersebut mencirikan perbedaan kualitatif antara ekstroversi (yaitu kesadaran langsung) dan introversi (yaitu kesadaran yang mengalami perpindahan) (Chafe, 1994). Ciri-ciri tersebut muncul dalam teks sebagaimana berikut ini.

\section{Kontinuitas}

Penggalan cerita (1) mengandung kontinuitas yang mengilustrasikan kesadaran dalam moda langsung atau moda imediasi.

(1) Suatu kali, aku masih ingat waktu itu - aku bermimpi menemu uang satu sen. Dan waktu aku membukakan mata, tanganku tergenggam rapat agar uang yang kutemu tidak hilang. Segera aku bangun dan mendapatkan bunda. Berseru riang: "Ibu, ibu, aku menemu uang sesen".

Dan aku lihat juga bunda tersenyum turut bergembira hati. Memperlihatkan kegembiraannya, ia bertanya: "Di mana engkau menemunya? Mana uangnya?"

Kuacungkan genggaman tanganku padanya. Teriakku senang: "Ini! ini!"

Kemudian genggaman itu kuurai. Tapi tangan itu kosong saja. Dan bunda menyusulkan suaranya yang manis itu: "Mana?"

Aku tertegun oleh kaget dan kecewa karena uang yang kutemu dalam impian tak ada dalam genggaman. Dan aku menangis oleh kekecewaan. Dan terdengar olehku bunda tertawa. Kemudian membujuk-bujuk: "Engkau baru bangun tadi. Engkau bermimpi tadi. Jangan menangis."

Tapi kekecewaan itu masih juga menggulung-gulung dalam dadaku. Dan aku meneruskan tangisku, bunda mengusap air mataku dengan ujung kebayanya. "Diam. Diam," katanya lagi.

Dikeluarkannya uang setengah sen dari lipatan ambennya dan diulurkannya padaku. Dan aku diam sambil mempermainkan uang setengah sen dengan masih ada setengah dari kekecewaan itu di dalam dada.

"Sudah sore sekarang," kata bunda, "sana mandi. Minta mandi nyi Kin." 
Dan aku pun berdiri dari pangkuan ibu. Tapi aku tak juga pergi untuk dimandikan. Aku lihat paras bunda jadi keruh. Kemudian terdengar suaranya yang tak lunak lagi dan mengandung kepastian: "Pergi."

Kepastiannya itu pula yang membuat aku bangun dan berjelan lambat-lambat mencari nyi Kin di dapur. Dari belakangku terdengar suara yang memperingatkan: "Cepat! Sudah sore sekarang."

Kepastiannya itu pula yang membuat aku tak berani menangis. Pelahan aku pergi mendapatkan nyi Kin di dapur minta mandi (hlm. 2-3)

Rangkaian kejadian yang disertai tindakan protagonis dan tokoh Bunda mengalir tanpa interupsi dalam (1), dengan demikian membuat rangkaian itu melaju secara berkelanjutan. Kejadian dimulai setelah narator menyatakan ia ingat tentang mimpinya di satu waktu pada masa kecilnya, lalu diikuti dengan rangkaian kejadian sampai potongan itu selesai. Nampak pula dalam (1) rangkaian kejadian yang mengalir itu memiliki urutan linear ke depan secara temporal, sehingga mengikat serangkaian tersebut walaupun apabila disimulasikan dalam realitas rangkaian itu relatif singkat.

Terdapat pula dalam (1) artikulasi definit terhadap nada suara Bunda, yakni 'yang manis itu' dan yang 'yang tak lunak lagi dan mengandung kepastian'. Selain itu ada juga penyebutan nama 'Nyi Kin' tanpa ada pengenalan terhadap tokoh itu sebelumnya. Menariknya karakteristik nada bicara Bunda tidak dijelaskan sebelumnya dalam teks. Pembaca tidak punya wawasan mengenai hal tersebut. Dari sini maka, adalah narator/protagonist yang memiliki wawasan terhadap ragam nada bicara Bunda, yang kemudian membisakannya mempersepsika dan mencirikan nada bicara itu.

Dalam kata lain protagonis yang dikisahkan narator dalam teks tidak bisa membagi pengetahuan tentang hal-hal tersebut kepada siapapun. Namun, ia berpretensi bahwa ia punya pengetahuan mengenai hal-hal tersebut. Ini meninggalkan pengacuan ragam nada suara bunda dan nama-nama tadi kepada narator fiksional sebagai wawasan yang dimiliki oleh kesadaran diwakili.

Penemuan kontinuitas sebagai manifestasi moda imediasi yang lain ditemukan dalam (2):
(2) Dari depan rumah kami nampak pucuk rumpun-rumpun bambu yang hijau hitam. Bila angin meniup mereka bersuling-suling meliuk-liuk yang selalu menimbulkan perasaan takut dalam hatiku di waktu kecil. Segera aku lari ke pangkuan bunda dan menangis. Dan masih terdengar-dengar hingga kini bunda bertanya: "Mengapa menangis?"

Lain daripada (1), (2) mulai secara medias res, tidak ada perkenalan tentang siapa yang dimaksud dengan 'kami' yang mengimplikasi narator sebagai tokoh pencerita. Meskipun (2) memaparkan lokasi rumpun-rumpun bambu beserta warnanya, dan apa yang terjadi ketika angin meniup mereka, tetap ada yang tak terjelaskan di sini yaitu kedekatan antara rumah dengan rumpun-rumpun bambu. Kata depan' dalam (2) memberi informasi tentang orientasi rumah narator, namun kata itu kelihatannya juga menyiratkan pengetahuan jarak antara rumah dengan rumpun bambu hanya dimiliki narator.

Ciri seperti mirip dengan apa yang ditemukan dalam (1), sebagaimana telah dijelaskan sebelumnya. Meski dalam (2) terdapat frasa adverbial (yaitu: 'di waktu kecil') yang menerangkan konteks waktu masa lampau, apa yang dipaparkan dalam potongan teks tersebut memberikan kesan pengalaman langsung yang dialami alam sadar protagonist (yaitu: narator di masa kecil) secara berkelanjutan dan tanpa interupsi.

\section{Detil}

Detil dalam (3) tidak mengilustrasikan perincian yang halus. Tetapi itu tidak menghilangkan kualitasnya sebagai rincian atas suatu objek atau hal, yang aksesibilitasnya hanya kepada kesadaran ekstrovert.

(3) Aku lihat paras bunda jadi keruh. Kemudian terdengar suaranya yang tak lunak lagi dan mengandung kepastian. (hlm. 3)

(4) Kemudian bunda memyanyikan lagu daerah. Dan suaranya yang lembutlunak itu mendayu-dayu dan menidurkan ketakutanku. (hlm. 2)

(5) Di lubang atap yang berbentuk segitiga itu nampak olehku sebuah kepala besar menjenguk-jenguk. (hlm. 9)

Detil yang ada pada (3), (4), dan (5) masih bisa diperhalus dalam arti, paras keruh Bunda dapat diperjelas deskripsi persisnya. Begitu juga 
dengan suara yang lembut-lunak itu mendayudayu, dan penampilan kepala besar yang dilihat narator selaku protagonis masih bisa diperinci. Namun demikian, detil sendiri adalah ciri-ciri kualitatif kesadaran yang ada dalam moda lansung atau ekstroversi. Ini karena kesadaran memiliki titik perhatian atau atensi yang bisa menggiling detil di lingkungan secara langsung ketika dalam keadaan ekstrovert. Maka, contoh-contoh tersebut mengilustrasikan kesadaran diri protagonist dalam cerita sedang berinteraksi dengan lingkungan sekitarnya secara direk.

\section{Imediasi Deiksis}

Menariknya, dalam hal ini teks Yang Sudah Hilang karya Pramoedya tidak memiliki katakata yang mengilustrasikan imediasi deiksis. Walaupun demikian keberadaan kontinuitas dan detil sebagai ciri-ciri kesadaran dalam moda imediasi menyatakan keberadaan moda imediasi di dalam teks.

\section{Moda Perpindahan}

Ditemukan dalam teks beberapa contoh perpindahan yang menunjukkan keberadaan moda perpindahan.

(6) Suatu kali, aku masih ingat waktu itu .... (hlm. 2)

(7) Hingga kini aku masih bisa membayangkan nyi Kin. (hlm. 3)

(8) Masih terang dalam ingatanku hingga kini betapa pada suatu hari aku ketakutan mendekati bunda. (hlm. 15)

(9) Kalau waktu itu aku bisa mengatakan, pastilah kukatakan, bahwa sesungguhnya bunda sedang kehilangan tempat berlindungnya yang kadang-kadang diharapkannya di kala ia membutuhkan tempat pelarian. (hlm. 23)

Persamaan antara (6) dan (9) adalah terdapat frasa adverbia waktu itu di keduanya. Frasa tersebut mengacu kepada suatu masa spesifik di masa lalu yang mendahului pernyataan itu sendiri. Lalu, pada (6), (7), dan (8) terdapat adverbia masih yang mendenotasi suatu keberlangsungan durasi yang berhubungan dengan kejadian, keadaan, dan agen yang spesifik.

Dengan frasa dan adverbia tersebut narator menyituasikan kejadian di masa lampau. Acuan terhadap keadaan, kejadian, dan agen spesifik itu datang dari memori narator selaku diri yang berkesadaran. Ini menyimulasikan narator tengah mengisahkan memori atau ingatannya kepada audiens takspesifik. Dalam hal ini pembaca bisa dipertimbangkan sebagai audiens takspesifik.

Mengisahkan pembaca secara langsung kepada pembaca selaku audiens takspesifik memperjelas peran narator sebagai instansi pencerita. Sebagai diri berkesadaran narator bersifat proksimal karena kedekatannya dengan pembaca. Dan, pengingatan kesadaran narator jadi introvert, atau melihat ke dalam dirinya untuk mengakses memori masa lampau. Seketika narator mengilas balik kesadarannya di suatu keadaan atau kejadian masa lampau, kesadaran narator mengalami perpindahan.

\section{Sudut Pandang Orang Pertama}

Penggunaan pronomina orang pertama ' $a k u$ ' dalam teks bisa dilihat dari (1) sampai (8). Bahkan pembaca bisa menemukannya di seluruh teks. Menariknya, seorang pembaca tidak mengetahui identitas narator/protagonist yang mengutarakan dirinya sebagai ' $a k u$ '. Ini sesederhana karena pembaca tidak disuguhkan dengan nama narator selaku protagonis dalam cara apapun.

Pronomina 'aku' digunakan untuk mengacu kepada dirinya sendiri sebagai narator di masa sekarang, dan dirinya sendiri sebagai protagonis yang mengalami kejadian-kejadian langsung di masa lampau. Pronomina orang pertama itu memberikan sudut pandang yang membangun konteks waktu lampau dan sekarang.

Terbangunnya konteks itu tidak hanya menegaskan presensi dan peran kesadaran mewakili. Konteks itu juga menegaskan kesadaran diwakili. Dalam kata lain, konteks yang dibangun sudut pandang orang pertama memberi perbedaan masa antara kesadaran ekstrovert dan kesadaran introvert. Di saat yang sama sudut pandang pronominal ' $a k u$ ' menyatakan koinsidensi dua kesadaran dari seorang diri.

Properti konstan kesadaran diri (yaitu: tindakan, persepsi, dan evaluasi) yang ditemukan dalam teks mendukung pernyataan barusan. Pernyataan yang menerangkan persepsi dicontohkan oleh (10), (11), dan (12). 
(10) Dan aku lihat juga bunda tersenyum turut bergembira hati. (hlm. 2)

(11) Dan tangannya yang tak lembut lagi seperti semasa gadisnya mengusapusap pipiku yang kurus. (hlm. 2)

(12) ...bunda masih terdengar mengaji (hlm. 13)

Pernyataan dalam (10), (11), dan (12) mengacu ke pemaparan pengalaman sadar secara perseptual milik diri berkesadaran ' $a k u$ '. Masing-masing contoh pernyatan bersumber kepada salah satu panca indra. Pernyataan (10) misalnya, dengan jelas merujuk kepada indra penglihatan, sementara (11) peraba dan (12) pendengaran atas apa yang ada di lingkungan sekitarnya.

Pengalaman sadar atas tindakan yang ditemukan dalam teks dicontohkan oleh (13) dan (14).

(13) Segera aku lari ke pangkuan bunda dan menangis. (hlm. 2)

(14) Aku pandangi muka besar itu dengan diam-diam sambil menggerumiti kerak nasi goreng. (hlm. 9)

Pernyataan (13) dan (14) mengacu kepada tindakan berbeda yang dialami ' $a k u$ ' secara sadar. Sementara (13) menerangkan kesadaran diri atas tindakan 'lari' dan 'menangis', (14) menerangkan 'pandangi' dan 'menggerumiti' secara diam-diam. Selanjutnya, ditemukan pula pengalaman sadar evaluasi milik diri yang dinyatakan oleh ' $a k u$ ' di dalam teks.

(15) Dan aku... masih ada setengah dari kekecewaan itu di dalam dada. (hlm. 3)

(16) Dan semua itu pun telah habis terseret dan takkan mungkin datang kembali (hlm. 14)

Evaluasi mengacu kepada pengalaman atas halhal yang diproses dalam diri secara internal. Contoh-contoh yang ditemukan dalam teks menerangkan perasaan dan opini narator. 'Kekecewaan' dalam (15) menerangkan keadaan emosional protagonis seketika mengalami kejadian langsung yang tak dikehendakinya. Sementara (16) menjelaskan pandangan konklusif soal segala sesuatu yang pernah terjadi dalam hidupnya di masa lampau.

Selanjutnya, (17) adalah salah satu introspeksi yang ditemukan dalam teks.
(17) Ada dua puluh lima kali cerita itu diulang-ulangnya, dan aku mendengarkan dengan perhatian penuh.

(18) Suara itu hanya terdengar beberapa detik saja dalam hidup. Getaran suara yang sebentar saja berdengung, takkan terulang lagi.

(19) Semua itu sudah hilang dari jangkauan pancaindera.

Introspeksi mengacu kepada meta-kesadaran atas kegiatan yang dilakukan kesadaran. Di sini, yang dinyatakan dalam (17) adalah kesadaran narator atas pengingatannya atas cerita Nyi Kin, jumlah repetisi dari penceritaan, dan kesadaran atas pengalaman perseptual beserta sikapnya seketika mengalami penceritaan itu. Selanjutnya (18) dan (19) menerangkan kepekaan penuh narator selaku kesadaran proksimal mengenai apa yang tengah dialami dan dilakukan alam sadarnya terkait kejadian dan keadaan di masa lampau.

Ditemukan pula dalam teks Yang Sudah Hilang sudut pandang diri (yaitu narator) yang dicerminkan deiksis spasial dengan cara yang harfiyah. (20) dan (21) merupakan ilustrasi dari deiksis spasial. Deiksis spasial yang dicontohkan dua poin di bawah menjangkarkan titik fisikal kesadaran diwakili.

$$
\begin{aligned}
& \text { (20) Dari belakangku terdengar suara } \\
& \text { yang memperingatkan: "Cepat! } \\
& \text { Sudah sore sekarang." (hlm. 3) } \\
& \text { (21) Diraihnya aku dan ditidurkan di } \\
& \text { sampingnya. (hlm. 15) }
\end{aligned}
$$

Deiksis spasial menjadi sudut pandang dan sumber acuan atas kejadian dan keadaan yang dialami kesadaran diwakili selaku protagonis. Titik fisikal penjangkar sudut pandang ini memberi tahu orientasi protagonis dan arah datangnya suara bunda, sebagaimana yang dicontohkan (20). Sementara (21) menerangkan orientasi dan letak diri protagonis dengan memandang keberadaan posisi Bunda.

\section{Pengakuan Okasional atas Kesadaran Mewakili} Narator diberi pengakuan dalam teks Yang Sudah Hilang. (22), (23), dan (24) adalah ungkapan-ungkapan yang memberi pengakuan kepada kesadaran mewakili.

(22) Dan masih terdengar-dengar hingga kini bunda bertanya: "mengapa menangis?" (hlm. 1) 
(23) Aku masih ingat betul hingga kini, begitulah ceritanya. (hlm. 5)

(24) Pengertian kanak-kanakku tak dapat menangkap apa yang dimaksudkannya. Tahunan kemudianlah aku baru mengerti apa yang dimaksudkannya. (hlm. 24)

Kesamaan tiga potongan di atas adalah bahwa masing-masing menyatakan sesuatu kejadian atau keadaan distal di masa lampau yang memiliki keterkaitan dengan kesadaran mewakili proksimal sebagai instansi pencerita atau narator. Pernyataan yang dicontohkan ketiganya menerangkan bahwa pengalaman langsung kesadaran ekstrovert (atau protagonis) adalah milik kesadaran introvert (atau narator). Dalam kata lain, pengakuan tersebut menghasilkan kongruensi antara kesadaran mewakili dengan kesadaran diwakili.

Kongruensi antara dua kesadaran tersebut menerangkan bahwa kedua kesadaran itu milik satu diri yang sama. Masing-masing pernyataan mengacu kepada pengalaman diri sebagai protagonis. Pengalaman itu tersimpan dalam memori, dan dikisahkan oleh diri pemilik pengalaman sebagaimana ia bertindak selaku narator. Ingatan narator dalam (22) menerangkan pengalamannya di keadaan langsung sewaktu mendengar pertanyaan Bunda, dan ingatan tentang pengalaman perseptual tersebut. Sementara (23) menerangkan pengetahuan protagonis atas suatu cerita yang menetap dan tidak berubah dari masa kecilnya sampai ia menceritakannya di titik proksimal atau dekat dengan pembaca.

Lain dari (22) dan (23), kongruensi dari pengakuan okasional terhadap kesadaran mewakili dalam (24) mengimplikasi kesadaran mewakili, atau narator, memiliki pengetahuan utuh atas kesadaran diwakili ekstrovert yang mengalami kejadian atau keadaan secara direk. Perlu diperjelas bahwa pengetahuan kesadaran mewakili adalah pengalaman kesadaran diwakili. Pengetahuan itu aksesibel sebagaimana dimiliki oleh diri yang sama, namun berkesadaran terpisah secara spasiotemporal.

Lebih lanjut, (22) menyatakan evaluasi kesadaran proksimal introvert, selaku narator, terhadap pemahamannya mengenai ucapan Bunda. Pemahaman yang diacu dalam (23) mengambil situasi di masa lampau, sebagaimana dialami kesadaran diwakili ekstrovert. Di kalimat berikutnya dalam (24) narator memberikan pernyataan evaluatif atas pemahamannya. Namun demikian situasi yang diacu tetap di masa lampau, dan di saat yang sama pernyataan itu mereferensikan waktu yang berbeda.

Lebih jelasnya, terdapat dua titik yakni ketika protagonis pertama kali mendengar dan tidak mengerti ucapan Bunda, dan ketika ia akhirnya memahami ucapan itu. Maka ada pergerakan temporal dalam pernyataan itu, yang meliputi pengetahuan kualitas pemikiran protagonis mengenai dirinya sendiri sebagaimana dimanifestasikan kesadaran diwakili. Di sini nampaknya (24) persis dengan (22) dan (23) dalam caranya mengimplikasi pengalaman langsung kedaran diwakili aksesibel bagi kesadaran mewakili, sebagaimana hal itu milik diri yang sama.

\section{DISKUSI}

\section{Model Situasi Penceritaan Memori Masa Silam Terfragmentasi dan Ironi Dramatik}

Telah disebutkan sebelumnya bahwa dalam teks Yang Sudah Hilang Pram merekayasa satu diri fiksional dengan dua kesadaran yang beroperasi dalam perannya masing-masing, dan memiliki keterikatan satu sama lain. Desituasi kedekatan bahasa secara fisik dan situasi sosial membuat kopresensi antara pemroduksi bahasa (Pram) dengan bahasa yang diproduksi (teks) jadi terikat secara lemah. Dalam hal ini diri fiksional melakukan pretensi mengingat tanpa batas, sebagaimana hal yang lazim dan suatu pengingatan khusus dalam fiksi, yang membuat kesadaran diwakili mengalami ulang kejadian dan keadaan masa silam yang dikisahkan kesadaran mewakili.

Ditemukan pula di dalam teks ciri-ciri kualitatif ekstroversi, atau keadaan kesadaran dalam moda langsung, setidaknya berupa kontinuitas dan detil. Ketiadaan imediasi deiksis (atau deiksis langsung) bisa dipertanyakan di sini, ketimbang dijadikan hal yang menyangsikan keberadaan moda langsung: sejauh mana ketiadaan deiksis langsung berpengaruh terhadap model situasi?

Ketiadaan deiksis langsung menyimulasikan penceritaan yang terjadi dalam teks sebagaimana suatu percakapan. Maksudnya, 
Yang Sudah Hilang tidak menyituasikan seseorang pencerita yang meriwayatkan masa lalunya melainkan, narator berlaku sebagai seseorang yang mengajak pembaca seolah-olah membincangkan masa lalunya. Dalam hal ini pengalaman ulang kesadaran diwakili selaku protagonist bersifat skematik dengan ketiadaan deiksis langsung. Ini mengimplikasi kejadian dan keadaan yang diceritakan narator hanyalah bagian-bagian kenangan yang relevan bagi dirinya sehingga tidak memerlukan penjangkaran spasiotemporal dalam konteks langsung. Selain itu, detil yang ditemukan dalam teks nampaknya tidak tergiling secara halus atau tak begitu terperinci.

Perpindahan kesadaran ke kesadaan di masa lampau (atau kesadaran dalam moda perpindahan) dimanifestasikan oleh frasa adverbia yang merupakan ekspresi kolokial, yang seringkali meliputi kata adverbia duratif. Kelihatannya ekspresi tersebut memberi informasi terkait konteks kejadian dan keadaan dalam ranah temporal. Dalam kata lain, pembaca dapat mengetahui pemaparan instansi pencerita atau narator sebagai pengalamannya yang telah silam, terima kasih kepada ekspresi tersebut. Selain itu, kesan simulasi percakapan dari penceritaan narator semakin nampaknya lebih kuat dengan adanya frasa adverbia kolokial yang ada di dalam teks, sementara adverbia duratif menerangkan keterhubungan masa lalu dengan masa sekarang (titik penceritaan narator). Dengan demikian saya berargumen bahwa simulasi percakapan dalam penceritaan pengalaman yang dihasilkan oleh keterhubungan dua moda kesadaran beroperasi sebagaimana membuat kisah masa silam itu terfragmentasi.

Sampai sini saya ingin menarik implikasi dari temuan moda perpindahan dalam Yang Sudah Hilang ke dalam lingkup pengalaman pembuatan makna dari bahasa Indonesia. Dalam menunjuk keberadaan moda perpindahan, dalam bukunya Chafe sesederhana menunjuk kala lampau yang tertulis pada suatu teks fiksi berbahasa Inggris, yang secara sistematik terlengkapi dengan bentuk lampau. Implikasi yang ingin saya tarik di sini berupa mempertanyakan sejauh mana pengalaman pembuatan makna bergantung kepada frasa adverbia atau kata adverbia dalam bahasa Indonesia.
Dalam kata lain, haruskah moda perpindahan selalu bergantung kepada hal-hal tersebut dalam bahasa Indonesia secara tulisan maupun lisan, dan efek pemaknaan apa yang terjadi secara eksperiensial ketika frasa atau kata adverbia tidak digunakan? Sekiranya, untuk sekarang sulit sekali menjawab pertanyaanpertanyaan tadi di sini. Spekulasi yang bisa saya tawarkan adalah pembaca akan menemukan pengalaman langsung protagonis atau pembicara apabila frasa dan kata adverbia tidak digunakan. Tetapi untuk mengetahui lebih jelasnya, butuh kajian bermetodologi solid untuk mencari jawaban yang akurat. Dengan demikian, selain menarik, kajian yang mempersoalkan pertanyaan-pertanyaan tadi dapat disarankan.

Selanjutnya teks Yang Sudah Hilang memiliki sudut pandang pertama, baik sebagai narator maupun protagonis, yang rupanya tidak diperkenalkan kepada pembaca namanya. Maksudnya pembaca hanya diberikan informasi tentang 'aku' sebagai instansi pencerita dan pelaku pengulang pengalaman dari apa yang diceritakan. Dalam perspektif orang pertama ditemukan properti variabel kesadaran lengkap (yaitu: persepsi, tindakan, evaluasi, dan introspeksi), dan keberadaan deiksis spasial yang menerangkan orientasi sudut pandang terhadap stimulus di lingkungan langsungnya.

Tidak diperkenalkannya narator, atau tak disebutkannya nama narator sebagai pemilik sudut pandang orang pertama kelihatannya mengimplikasi simulasi percakapan sebagai gaya bercerita narator di dalam teks. Dalam hal ini pembaca diperlakukan seolah telah mengenali narator, atau memiliki kedekatan sosial terhadap narator, sehingga ia bisa saja menceritakan masa lalunya yang telah hilang itu. Di sini kita bisa mengaitkan implikasi tersebut dengan lengkapnya properti variabel kesadaran.

Kelengkapan properti variabel kesadaran memperkuat keberadaan satu diri dengan dua kesadaran dan pengetahuan utuh atas memori yang dikisahkan. Diri tersebut merasa kehilangan orang-orang yang terlibat kejadian dan keadaan di masa yang diceritakannya. Memori yang dikisahkan diri tersebut adalah kehilangan yang dialaminya. Mengaitkan hal barusan dengan simulasi percakapan yang 
timbul dalam teks, yang dikisahkan dalam Yang Sudah Hilang adalah fragmen memori. Fragmen memori ini bersifat skematik, atau tersimplifikasi, mengingat detil yang dipaparkan di dalamnya. Dan, tipikal pada memori yang bersifat skematik adalah bahwa hal yang diingat merupakan yang paling relevan terhadap kejadian atau keadaan yang diingat. Atas dasar itu saya berpendapat pembaca menemukan penceritaan memori masa silam terfragmentasi, yang dilakukan dengan gaya percakapan sehari-hari, sebagaimana diisyaratkan oleh lompatanlompatan topik di dalam teks.

Dalam teks Yang Sudah Hilang terdapat kesadaran diberikan pengakuan melalui pembahasaan yang muncul, yang menerangkan kongruensi pengalaman protagonis (sebagai kesadaran diwakili ekstrovert) dengan memori yang diceritakan oleh narator (sebagai kesadaran mewakili introvert). Selain memperkuat bahwa dua kesadaran tersebut saling berhubungan dan milik satu diri yang sama, pengakuan itu mengimplikasi pergerakan temporal diri yang menceritakan masa lalunya sehubungan keadaan internalnya ketika mengalami kejadiaan dan keadaan secara langsung di masa itu. Ini juga mengimplikasi hubungan antara kejadian dan keadaan di masa lalu dengan keadaan diri yang bercerita di titik penceritaannya.

Apa yang nampak dari pemaparan barusan adalah meskipun dua kesadaran itu milik satu diri yang sama, tetapi ada perbedaan pemahaman atas kepemilikan pengalaman yang diceritakan dalam teks. Bila dicermati justru narator (kesadaran mewakili) yang memahami betul kejadian dan keadaan yang ia alami, bukan protagonis (kesadaran diwakili). Pasalnya, adalah narator yang berkomentar atas kejadian dan keadaan yang diceritakan sebagai pengalaman yang dikenang dalam teks. Di titik penceritaan adalah narator pula yang memeiliki kesadaran dan pengetahuan penuh atas kehilangannya, walaupun hampir semua penjelasan mengenai bagaimana kehilangan itu terjadi diserahkan kepada proses inferensial pembaca.

Mengilas balik yang telah didiskusikan sebelumnya, saya mengklaim bahwa model situasi dalam teks Yang Sudah Hilang adalah penceritaan, kalau bukan pengenangan, memori masa silam terfragmentasi. Mengapa disebut pengenangan, karena narator memiliki kepekaan penuh atas pengilaman kehilangan yang ia telah alami, sebagaimana yang diceritakannya. Dalam kata lain, model situasi ini merepresentasikan diri yang bercerita dan mengalami ulang pengalamannya secara introspektif.

Terdapat pula disonansi antara kesadaran ekstrovert distal (protagonis yang mengalami ulang pengalamannya) dengan kesadaran introvert proksimal (narator yang menceritakan pengalamannya). Disonansi mengisyaratkan bahwa yang kedua dapat memahami kejadian dan keadaan di masa lalu, sebagaimana ia memberi komentar atas hal itu, sehingga memberikan pengakuan okasional kepada kesadaran mewakili. Maka dari itu model siatuasi dalam teks mempertemukan pembaca dengan sosok pencerita yang sewaktu kecil awam terhadap kejadian dan keadaan di sekitarnya, namun di titik penceritaan memahami apa yang telah dialaminya waktu itu.

Dengan disonansi yang ada, model siatuasi dalam teks Yang Sudah Hilang juga membangun ironi dramatik, suatu keadaan ironis luput dari pengetahuan tokoh cerita tetapi diketahui pembaca. Di awal cerita narator memberi pernyataan,

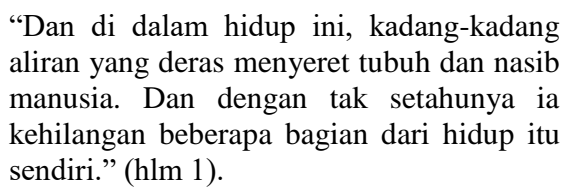

"Dan di dalam hidup ini, kadang-kadang aliran yang deras menyeret tubuh dan nasib manusia. Dan dengan tak setahunya ia kehilangan beberapa bagian dari hidup itu sendiri." (hlm 1).

Meski narator kelihatannya tahu betul tentang kehilangannya, dan mengerti sepenuhnya atas keawamannya terhadap kejadian dan keadaan di masa kecil, tetapi terdapat kesan ia tidak menyadari bahwa bukanlah kehidupan itu sendiri yang membuatnya kehilangan orangorang penting dari hidupnya.

Seseorang dapat mempelajari dari teks bahwa, waktu kecil, narator sengaja dibiarkan awam oleh orang tuanya. Pembiaran ini membuat narator tidak mengetahui secara pasti apa yang menyebabkan kehilangannya, walaupun ia mengetahui dirinya mengalami kehilangan. Narator memang tahu penyebab Nyi Kin berhenti jadi pembantu rumah tangga bundanya. Tapi itupun setelah ia menerima 
alasan palsu di pertama kali bunda menjelaskan.

Lebih lanjut, apa yang dinyatakan narator sebagai 'telah hilang' terbilang ambigu di sini, sehingga pembaca belum tentu bisa mencerap maksudnya. Narator tahu ada bunda dan ayah, yang memberi perkataan, perhatian, tindakan, dan lain-lain. Mereka tergolong sebagai hal 'yang telah hilang' bagi narator. Tetapi, dalam menyatakan hal itu narator tak memberikan penjelasan atau apapun mengenai penyebab, bagaimana kehilangan itu terjadi, dan apa yang sebenarnya ia maksud dengan hilang.

Satu hal yang memperkuat ironi dramatik dalam model situasi teks adalah, bahwa kelihatannya tidak menyadari ia bisa berbuat sesuatu untuk melawan kehilangan itu. Narator telah mengalami kehilangan di titik penceritaan. Melalui penceritaannya pembaca tahu bahwa narator tengah mengintrospeksi masa lalunya. Tadi dikatakan bahwa di narator awam atas kejadian dan keadaan yang dialami secara langsung. Keawaman itu membuatnya tak berdaya kecuali menerima kehilangan yang menimpanya, sebagaimana keawaman itu pula yang membuatnya tidak mengupayakan apapun untuk mencegah terjadinya kehilangan tersebut.

Model situasi diperoleh melalui inferensi atas apa yang muncul pada teks (van Dijk \& Kintsch, 1983) dan dengan menginterpretasikannya melalui kerangka kerja teoretik moda kesadaran dalam tulisan fiksi orang pertama (Chafe, 1994). Beberapa hal bisa disampaikan di sini. Pertama, model situasi yang ditawarkan di sini minim hubungan dengan fenomena-femona dalam feminisme, meski terdapat kesan yang bersinggungan dengan konteks pemikiran tersebut (bandingkan dengan Hayati, 2012). Memperjelas lebih jauh lagi, meskipun ada gejala fenomena yang bisa dipermasalahkan secara feministik, dalam makalah ini gejala tersebut jadi tidak kentara bila mengingat model situasi yang ada.

Selanjutnya, kelihatannya narator di dalam teks Yang Sudah Hilang sangat berperan, sebagaimana sosok dan pembahasaannya sengaja dikreasikan secara elegan oleh Pram, dalam membangun model situasi tadi dan juga dalam menggulirkan naratifnya (Gennette, 1980). Kendati demikian terdapat beberapa celah yang belum ditutupi oleh penelaahan ini. Apa yang ditemukan dan didiskusikan baru menawarkan model situasi, yang dalam dirinya sendiri belum menyentuh ranah pembahasaan dalam teks terkait pengalaman makna. Pernyataan repetitif tentang kehilangan narator di dalam teks boleh jadi suatu hal yang menarik untuk penelaahan lebih lanjut. Selain itu implikasi bahasa yang tadi disinggung sebelumnya juga bisa menjadi topik pertanyaan dalam kajian di masa depan.

\section{KESIMPULAN}

Makalah ini menawarkan interpretasi tekstual tersendiri atas teks Yang Sudah Hilang karya Pram, dengan menggunakan kerangka pikir teoretik yang memperhitungkan pembahasaan secara objektif dan proses inferensial hasil pengalaman baca. Interpretasi yang ditawarkan di sini mengisyaratkan kecakapan penulis dalam bermain bahasa dalam karya fiksi, pengalaman pembuatan makna yang dihasilkan oleh bahasa dalam karangan fiksional dalam teks ini, dan model situasi meta-narasi yang rupanya tidak menyinggung pemikiran ideologis yang pernah diajukan dalam kajian lain. Dengan demikian makalah ini juga telah menghasilkan perspektif berbeda dalam memahami karya Pram yang minim perhatian penelaahan tekstual. Makalah ini mendemonstrasikan kemampuan semiotika kognitif, yang tak lazim penggunaannya, dalam memprosesi teks. Hasil prosesi tekstual dari semiotik kognitif, setidaknya bila berkaca dari makalah ini, telah memberikan penerangan yang memperhatikan dasar objektif dengan penalaran eksperiensial yang mengimplikasi empirisme.

\section{UCAPAN TERIMAKASIH}

Makalah Ini Selesai Terima Kasih Kepada Rekan-Rekan Sejawat Yang Telah Memberi Saran, Komentar, Dan Kritik Konstruktif.

\section{DAFTAR PUSTAKA}

[1] R. Bahari, Pramoedya Postcolonially: Re-viewing History, Gender, and Identity 
in the Buru Tetralogy, NIE Malay Collective, 2007

[2] W. Chafe, Discourse, consciousness, and time: The flow and displacement of conscious experience in speaking and writing, University of Chicago Press: 1994

[3] R.Dirven, \& M.Verspoor, Structuring texts: text linguistics, Cognitive exploration of language and linguistics. 1998, p.193-216.

[4] C. Emmott \& M. Alexander, Schemata. 2014

[5] H.T.Faruk, Kisah Penjara Etis Dan Filosofis: Analisis Lintas Budaya Atas Tembok Tidak Tinggi Karya A. Samad Ismail Dan Mereka Yang Dilumpuhkan Karya Pramoedya Anantatur, Humaniora, 20(2), 2008,p.224-235.

[6] K.Foulcher," Bumi Manusia" and" Anak Semua Bangsa": Pramoedya Ananta Toer Enters the 1980s. Indonesia, (32), 1981, p.1-15.

[7] S.Friend, VIII-Fiction as a Genre, In Proceedings of the Aristotelian Society (Hardback), Vol. 112, No. 2pt2, p. 179-209, Blackwell Publishing Ltd. 2012

[8] Genette,Narrative discourse (JE Lewin, Trans.),Ithaca, NY: Cornell UP,1980

[9] C.L.GoGwilt, The Voice of Pramoedya Ananta Toer: Passages, Interviews, and Reflections from The Mute's Soliloquy and Pramoedya's, North American Tour, Cultural Critique, 55(1),2003, 217246.

[10] Hayati, Y. Representasi Ketidakadilan Gender Dalam Cerita Dari Blora Karya Pramoedya Ananta Toer: Kajian Feminisme, ATAVISME, 15(2), 2012, p.163-176.
[11] D.Herman, Cognitive approaches to narrative analysis, Cognitive poetics: Goals, gains and gaps, 2009, p.79-118.

[12] M.Muzakka, Novel Gadis Pantai Karya Pramoedya Ananta Toer: Analisis

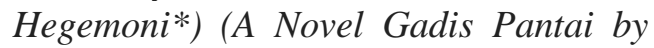
Pramoedya Ananta Toer: an Hegemony Analysis), ALAYASASTRA, 13(1), 2017, p. 13-20.

[13] C.Niekerk, Rethinking a problematic constellation: postcolonialism and its Germanic contexts (Pramoedya Ananta Toer/Multatuli), Comparative Studies of South Asia, Africa and the Middle East, 23(1), 2003, p.58-69.

[14] J.Roosa \& A.Ratih, Solipsism or Solidarity: The Nation, Pramoedya Ananta Toer and Salman Rushdie, Economic and Political Weekly, 2001, p.2681-2688.

[15] F.K.Stanzel, Teller-characters and reflector-characters in narrative theory, Poetics Today, 2(2),1981, p.5-15.

[16] Supriyadi, Novel Gadis Pantai Karya Pramoedya Ananta Toer: Analisis Berdasarkan Konsep Androgini. Humaniora, 17(2), 2005, p.195-203.

[17] L.Talmy, 2000, A cognitive framework for narrative structure, Toward a cognitive semantics, 2, 2000, pp.417482.

[18] P.A.Toer, Cerita dari Blora: kumpulan cerita pendek, Hasta Mitra,1994

[19] Toer, P. A., \& GoGwilt, C. L, Pramoedya's Fiction and History: An Interview with Indonesian Novelist Pramoedya Ananta Toer, The Yale Journal of Criticism, 9(1), 1996, p.147164.

[20] T.A. Van Dijk \& W.Kintsch, Strategies of discourse comprehension, New York: Academic Press.1983.pp.11-12 